Available online on 15.3.2018 at http://ujpr.org
Universal Journal of Pharmaceutical Research
An International Peer Reviewed Journal
Open access to Pharmaceutical research

\title{
ETIOLOGY AND RISK FACTORS OF STOMATITIS AMONG YEMENI DENTURE WEARERS
}

\author{
Nesreen F. Al-Sanabani ${ }^{1}$ (D, Abbas M Al-Kebsi ${ }^{1}$, Hassan A. Al-Shamahy ${ }^{2}$ (D), Al-Kasem M A Abbas ${ }^{3}$ \\ ${ }^{1}$ Department of Prosthodontics, Faculty of Dentistry, Sana' a University, Republic of Yemen. \\ ${ }^{2}$ Medical Microbiology and Clinical Immunology, Faculty of Medicine and Health Sciences, Sana' a University. \\ ${ }^{3}$ Department of Maxillo-Facial, Faculty of Dentistry, Sana'a University, Republic of Yemen.
}

\section{ABSTRACT}

Objectives: Denture stomatitis (DS) is a benign condition, usually asymptomatic, that can affect denture wearer's patients. The aim of this study was to describe the etiology of DS among Yemeni denture wearers and the risk factors of DS. A cross sectional study was carried out at Prothodontics Departments at the Faculty of Dentistry- Sana'a University, Sana'a city -Yemen.

Methods: The study group consisted of 288 denture wearers' patients' contracting DS. The microbiological samples were collected by wiping sterile swabs on upper and lower denture fitting surfaces. Then, they were directly cultured for Candida in Chromomeric agar media and for bacteria in standard selective media, using standard bacteriological methods.

Results: The most common microbial cause of DS was C. albicans $(58.3 \%)$, followed by $S$. mutans (17\%), while S. aureus (4.9\%), lactobacillus $(3.1 \%)$ and C. glabrata (4.2\%) were less common. There was an association between male patients, older age group and longer period of denture wearers with high risk of contracting candidal DS and bacterial DS. Most of those patients were suffering from DS Type I and few from Type II, but no case of DS Type III was found. Ending, DS is a condition that commonly affects denture wearers, and should be treated even if asymptomatic. The condition requires a combined treatment approach from both patient and clinician, and the role of the patient must be stressed.

Conclusion: Management of aetiological risk factors is key in order to prevent recurrence. Treatment modalities may include: treatment of any underlying systemic risk factors, improvement in the fit of existing dentures, replacement of existing dentures, improved denture hygiene and the use of antifungal agents. Whichever methods are employed, the main aim of treatment is to eradicate the biofilm from the patient's dentures.

Keywords: Bacterial DS, Candidal DS, Denture stomatitis (DS), DS risk factors, Sana'a city, Yemen.

Article Info: Received 11 December 2017; Revised 13 January; Accepted 27 February, Available online 15 March 2018
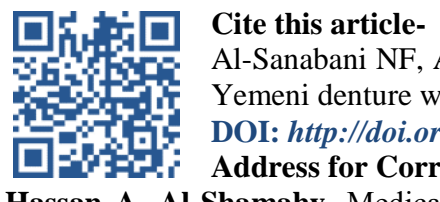

Al-Sanabani NF, Al-Kebsi AM, Al-Shamahy HA, Al-Kasem MAA. Etiology and risk factors of stomatitis among Yemeni denture wearers. Universal Journal of Pharmaceutical Research 2018; 3(1): 49-53.

DOI: http://doi.org/10.22270/ujpr.v3i1.R12

Address for Correspondence

Hassan A. Al-Shamahy, Medical Microbiology and Clinical Immunology, Faculty of Medicine and Health Sciences, Sana'a University, Republic of Yemen. Tel: +967-1-239551, E-mail: shmahe@yemen.net.ye.

\section{INTRODUCTION}

Denture stomatitis (DS) is a chronic inflammatory reaction commonly seen in denture wearing patients. Where mild inflammation and redness of the oral mucous membrane occurs beneath a denture ${ }^{1}$. The etiology is considered as multi factorial, with the prosthesis is considered as the prime etiologic factor. Etiological factors include poor denture hygiene, continual and night time wearing of removable dentures, accumulation of denture plaque, age of the denture and dryness of the mouth. Poor-fitting dentures may increase mucosal trauma which play a vital role in type I denture stomatitis and least importance in other types of DS, plaque on the inner surface of the denture harbors micro-organisms causing inflammation of the mucosa, bacterial and yeast contamination of denture surface in which $C$. albicans has been shown to be highly implicated in the etiology of DS and may account for $90 \%$ of cases ${ }^{2,3}$. C. albicans and S. aureus are microorganisms with an elevated adhesion capacity to the oral mucous. This adherence is enhanced in vitro when Candida is incubated simultaneously with Streptococcus mutans (S. mutans), Streptococcus sanguis ( $S$. sanguis), Streptococcus salivairus ( $S$. salivairus) or some other bacteria ${ }^{3}$. There are many predisposing factors for DS such as oral hygiene, old age, diabetes mellitus, trauma, xerostomia, high carbohydrate diet, use broad spectrum antibiotics and smoking tobacco ${ }^{4-6}$. Staging different classifications have been proposed, but the reference classification for DS is the one suggested by Newton in 1962, based 
exclusively on clinical criteria: According to Newton, it can be classified into 3 types:

Type 1- Localized simple infection with pinpoint hyperemia and is usually trauma induced ${ }^{7,8}$.

Type 2- Erythematous type, covers the entire or a part of the denture covering area ${ }^{7,8}$.

Type 3- Granular type, involving the central part of the hard palate and the alveolar ridge ${ }^{9}$. The aims of the study were to determine the different microbial causative agents of denture stomatitis and also detect the risk factors contributing for the severe cases of denture stomatitis (type II and type III).

\section{SUBJECTS AND METHODS}

Cross sectional study was carried out in the Prosthodontic department at the Faculty of DentistrySana'a University, from $11 / 2016$ to $2 / 2017$ on 288 Yemeni subjects (males and females), aged more than 35 years old. Data were collected by predesigned questionnaire. Samples were collected by wiping premoistened sterile cotton wool swabs on upper and lower denture fitting surfaces. Two swabs were collected for each patient one for mycological and the other for bacteriological investigation. For mycological investigations each sample was inoculated into both media: Sabouraud's dextrose agar and a differential and selective culture medium as Chrom agar Candida.
Plates were incubated aerobically for 48 to 72 hours at $37{ }^{\circ} \mathrm{C}$ and were identified systematically by Colonial morphology, wet mount preparation, gram stain and germ tube. However for bacteriological investigations samples of $S$. mutans and $S$. aureus were cultured into Mitis Salivarius-Bacitrac in agar and blood agar plate media and incubated at $35-37^{\circ} \mathrm{C}$ for 48 hours with addition $1 \%$ Potassium Tellurite. Then, were identified and differentiated from each other by their colonial morphology, catalase test, gram staining and microscopically examine, mannitol and sorbitol fermentation tests, hemolysis and coagulase test. But for Lactobacillus species, it were cultured overnight in MRS agar plate and incubated at $37^{\circ} \mathrm{C}$ and then it were identified by their colonial morphology, gram staining, growth at $15^{\circ} \mathrm{C}$ and growth at $45^{\circ} \mathrm{C}$ and catalase test.

Data collection: Data including demographic data of the patients, clinical information, and potential risk factors of DS. The findings were recorded in a form with laboratory results.

\section{Ethical approval}

We obtained written consent from all cases. Assent was taken from participants before collecting the specimens. The study protocol was reviewed and approved by the Ethics Committee of Sana'a University, Faculty of Medicine and Health Sciences.

Table 1: Sex and age distribution of patients suffering from denture stomatitis in the Prosthetic department at the Faculty of Dentistry-Sana'a University clinics from 11/2016 to 2/2017.

\begin{tabular}{|c|c|c|c|c|c|c|}
\hline \multirow{2}{*}{$\begin{array}{l}\text { Age groups } \backslash \\
\text { Years }\end{array}$} & \multicolumn{2}{|c|}{ Male $n=171$} & \multicolumn{2}{|c|}{ Female $n=117$} & \multicolumn{2}{|c|}{ Total $n=288$} \\
\hline & NO & $\%$ & NO & $\%$ & NO & $\%$ \\
\hline $35-44$ & 34 & 19.9 & 44 & 37.6 & 78 & 27.1 \\
\hline $45-54$ & 15 & 8.8 & 29 & 24.8 & 44 & 15.3 \\
\hline $55-64$ & 53 & 31 & 19 & 16.2 & 72 & 25 \\
\hline $65+$ & 69 & 40.4 & 25 & 21.4 & 94 & 32.6 \\
\hline Total & 171 & 59.4 & 117 & 40.6 & 288 & 100 \\
\hline Mean age & \multicolumn{2}{|c|}{$59.5 \mathrm{yrs}$} & \multicolumn{2}{|c|}{$52.1 \mathrm{yrs}$} & \multicolumn{2}{|r|}{$56.5 \mathrm{yrs}$} \\
\hline S.D & \multicolumn{2}{|c|}{$14.4 \mathrm{yrs}$} & \multicolumn{2}{|c|}{$16.02 \mathrm{yrs}$} & \multicolumn{2}{|r|}{$15.4 \mathrm{yrs}$} \\
\hline Median & \multicolumn{2}{|c|}{$60 \mathrm{yrs}$} & \multicolumn{2}{|c|}{48 yrs } & \multicolumn{2}{|r|}{$60 \mathrm{yrs}$} \\
\hline Mode & \multicolumn{2}{|c|}{$60 \mathrm{yrs}$} & \multicolumn{2}{|c|}{$35 \mathrm{yrs}$} & \multicolumn{2}{|r|}{$60 \mathrm{yrs}$} \\
\hline Max & \multicolumn{2}{|c|}{$85 \mathrm{yrs}$} & \multicolumn{2}{|c|}{$85 \mathrm{yrs}$} & \multicolumn{2}{|r|}{$85 \mathrm{yrs}$} \\
\hline Min & \multicolumn{2}{|c|}{$35 \mathrm{yrs}$} & \multicolumn{2}{|c|}{$35 \mathrm{yrs}$} & & 35 yrs \\
\hline
\end{tabular}

\section{RESULTS}

This study was conducted on a total of 288 patients contracting DS attending Prosthetic department at the Faculty of Dentistry- Sana'a University from 11/2016 to $2 / 2017$. Male patients were predominant in which they counted $59.4 \%$, while female patients were counted $40.6 \%$. The patients' age ranged from 35-65 years, and most of the patients were at the age group of +65 years, $(32.6 \%)$. The most common microbial causes of DS was C. albicans (58.3\%) of the total isolates, while $S$. mutans was the most common bacterial cause of DS(17\%), while S. aureus (4.9\%), lactobacillus $(3.1 \%)$ and C. glabrata $(4.2 \%)$ were less common. There was a highly significant association between male and high risk of contracting Candida albicans $\mathrm{DS}(\mathrm{OR}=2.33, \mathrm{CI}=1.4$ to 3.9 , and $p<0.001)$.
There was a highly significant association between older age group (65+ years) and the high risk of contracting Candida albicans $\mathrm{DS}(\mathrm{OR}=3.62$ times, $\mathrm{CI}=2$ to 6.6 , with $p<0.001$ ).

Table 2: The isolated microbes that cause denture stomatitis among patients attending the Prosthetic department at Faculty of Dentistry, Sana'a university clinics from $11 / 2016$ to $2 / 2017$.

\begin{tabular}{lcc}
\hline Micro-organisms & NO & \% \\
\hline S. mutans & 49 & 17 \\
S. aureus & 14 & 4.9 \\
Lactobacillus & 9 & 3.1 \\
C. albicans & 168 & 58.3 \\
C. glabrate & 12 & 4.2 \\
No pathogen & 36 & 12.5 \\
Total & $\mathbf{2 8 8}$ & $\mathbf{1 0 0}$ \\
\hline
\end{tabular}


Table 3: The association between candidal stomatitis and denture fitness and period of having denture.

\begin{tabular}{|c|c|c|c|c|c|c|}
\hline \multirow[t]{2}{*}{ Variables } & \multicolumn{2}{|c|}{$\begin{array}{l}\text { Candidal stomatitis } \\
\quad \mathrm{n}=168\end{array}$} & \multirow[t]{2}{*}{ OR } & \multirow[t]{2}{*}{ CI } & \multirow[t]{2}{*}{$\chi^{2}$} & \multirow[t]{2}{*}{$P$} \\
\hline & No & $\%$ & & & & \\
\hline \multicolumn{7}{|l|}{ Denture fitness } \\
\hline Good $n=52$ & 32 & 61.5 & 1.2 & $0.16-2.3$ & 0.27 & 0.6 \\
\hline Fair $n=99$ & 65 & 65.7 & 1.6 & $0.94-2.7$ & 3.3 & 0.06 \\
\hline Poor $n=137$ & 71 & 51.8 & 0.6 & $0.36-0.99$ & 4.55 & 0.03 \\
\hline \multicolumn{7}{|l|}{$\begin{array}{c}\text { Period of having } \\
\text { denture }\end{array}$} \\
\hline 6- 12 months $n=21$ & 17 & 81 & 3.26 & $1-11.8$ & 4.77 & 0.028 \\
\hline $\begin{array}{l}\text { 12- } 18 \text { months } \\
n=105\end{array}$ & 16 & 15.2 & 0.04 & $0.02-0.07$ & 126 & $<0.001$ \\
\hline $\begin{array}{c}\text { 18- over months } \\
n=162\end{array}$ & 135 & 83.3 & 14.1 & 7.66- 26 & 95.2 & $<0.001$ \\
\hline Total & 168 & 58.3 & & & & \\
\hline
\end{tabular}

Table 4: The association between bacterial stomatitis and denture fitness and period of having denture.

\begin{tabular}{|c|c|c|c|c|c|c|}
\hline \multirow[t]{2}{*}{ Variables } & \multicolumn{2}{|c|}{$\begin{array}{c}\text { Bacterial } \\
\text { stomatitis } \\
n=84\end{array}$} & \multirow[t]{2}{*}{ OR } & \multirow[t]{2}{*}{ CI } & \multirow[t]{2}{*}{$\chi^{2}$} & \multirow[t]{2}{*}{$p$} \\
\hline & No & $\%$ & & & & \\
\hline \multicolumn{7}{|l|}{ Denture fitness } \\
\hline Good $n=52$ & 5 & 9.6 & 0.21 & $0.07-0.58$ & 11.7 & $<0.001$ \\
\hline Fair $n=99$ & 9 & 9.1 & 0.15 & $0.07-0.33$ & 29.4 & $<0.001$ \\
\hline Poor $n=137$ & 70 & 51.1 & 10.22 & $5.2-20.6$ & 60.8 & $<0.001$ \\
\hline \multicolumn{7}{|l|}{ Period of having denture } \\
\hline 6- 12 months $n=21$ & 3 & 14.3 & 0.38 & $0.1-1.43$ & 2.43 & 0.11 \\
\hline $12-18$ months $\mathrm{n}=105$ & 21 & 20 & 0.48 & $0.26-0.87$ & 6.7 & $<0.001$ \\
\hline 18- over months $n=162$ & 60 & 37 & 2.5 & $1.4-4.5$ & 11.1 & $<0.001$ \\
\hline Total $\mathrm{n}=288$ & 84 & 29.1 & & & & \\
\hline
\end{tabular}

When denture fitness was considered, there was a highly significant association between the poor fitness and the high risk of contracting bacterial DS $(\mathrm{OR}=10.22$ times, $\mathrm{CI}=5.2$ to 20.6 , with $p<0.001)$. Also, there was a highly significant association between longer period of 18- over months and the high risk of contracting bacterial DS (the associated $\mathrm{OR}=2.5$ times, $\mathrm{CI}=1.4$ to 4.5 with $p<0.001)$. Most of patients were suffering from DS Type I in which it was counted $66.7 \%$, while only $33.3 \%$ of patients were suffering from DS Type II, but no case of DS Type III occurred in those patients. Also, there was a significant association between good fitness and the high risk of developed DS type II $(\mathrm{OR}=1.95$ times, $\mathrm{CI}=1.01$ to 3.7, with $\mathrm{p}=0.03$ ). When periods of having denture were considered, there was a highly significant association between longer period of 18- over months and the high risk of developed DS type II, $(\mathrm{OR}=10.2$ times, $\mathrm{CI}=5.03$ to 21.2 with $p<0.001$ ).

\section{DISCUSSION}

The most common microbial cause of DS in the present study was $C$. albicans $(58.3 \%)$ of the total isolates. This result was similar to that reported by Salerno and Zomorodian $^{1,10}$ in which the most common cause of DS was $C$. albicans. This occurrence of Candidal DS with high rate in denture wearers can be explained by the findings in which wearing denture was led to increase the chance of $C$. albicans oral colonization rate from 60 to $100 \%^{9-12}$. Oral colonization can be explained by the fact that dentures decrease the flow of oxygen and saliva to the underlying tissue producing a local acidic and anaerobic microenvironment that favours yeast overgrowth $^{13,14}$.

In this study bacterial denture stomatitis among those patients counted about $29.1 \%$ of the total isolates. This result was similar to that reported by Prabha in which bacterial denture stomatitis was the second cause after Candida albicans $\mathrm{DS}^{15}$. These results can be explained by the hypothesis of Harold Marcott ${ }^{16}$, who assumed that bacteria present in the saliva may also cause ulcer when there is alteration in the salivary $\mathrm{pH}$. Moreover, bacterial load in saliva increases due to caries, periodontal diseases and also other endocrine disorders like hypo-function of salivary glands which leads to decreased secretion and increased oral bacteria.

Table 5: Clinical classification of DS, xerostomia and co-systemic diseases among patients attending the Prosthetic department at the Faculty of Dentistry, Sana'a university clinics.

\begin{tabular}{lcc}
\hline Variables & Number & \% \\
\hline $\begin{array}{l}\text { Classification of Denture } \\
\text { stomatitis }\end{array}$ & 192 & 66.7 \\
$\begin{array}{l}\text { Denture stomatitis Type I } \\
\text { Denture stomatitis Type II }\end{array}$ & 96 & 33.3 \\
$\begin{array}{l}\text { Denture stomatitis Type III } \\
\text { Xerostomia }\end{array}$ & 0 & 0 \\
Systemic diseases & 0 & 0 \\
Diabetic mellitus & 6 & 2.1 \\
Hypertension & 16 & 5.6 \\
\hline
\end{tabular}


Table 6: The denture stomatitis type II associated with denture fitness and period of having denture.

\begin{tabular}{|c|c|c|c|c|c|c|}
\hline \multirow[t]{3}{*}{ Variables } & \multicolumn{2}{|c|}{ Denture stomatitis } & \multirow[t]{3}{*}{ OR } & \multirow[t]{3}{*}{ CI } & \multirow[t]{3}{*}{$\chi^{2}$} & \multirow[t]{3}{*}{$\mathbf{P}$} \\
\hline & type & $n=96$ & & & & \\
\hline & No & $\%$ & & & & \\
\hline \multicolumn{7}{|l|}{ Denture fitness } \\
\hline Good, $n=52$ & 24 & 46.2 & 1.95 & $1.01-3.7$ & 4.69 & 0.03 \\
\hline Fair, $n=99$ & 30 & 31.3 & 0.81 & $0.46-1.41$ & 0.62 & 0.42 \\
\hline Poor, $n=137$ & 42 & 30.7 & 0.79 & $0.5-1.34$ & 0.84 & 0.35 \\
\hline $\begin{array}{l}\text { Period of having } \\
\text { denture } \\
6-12 \text { months, } n=21\end{array}$ & 6 & 28.6 & 0.8 & $0.26-2.3$ & 0.23 & 0.6 \\
\hline 12- 18 months, $\mathrm{n}=105$ & 6 & 5.7 & 0.06 & $0.02-0.16$ & 56.7 & $<0.001$ \\
\hline 18 - over months, $n=162$ & 84 & 51.9 & 10.2 & $5.03-21.2$ & 57.1 & $<0.001$ \\
\hline
\end{tabular}

In this study, there was a highly significant association between males and the high risk of contracting Candida albicans DS $(\mathrm{OR}=2.33)$. The present study results supported the rejection of the null hypothesis which states that there would be no difference between male and female denture wearers in terms of the prevalence of Denture Related Stomatitis (DRS) and colonization by $C$. albicans of the inner surfaces of dentures and attachment surroundings. In a study by Gendreau and Loewy, a higher incidence has been reported in females ${ }^{17}$, but this is not always as in this case in which a higher incidence has been reported in males ${ }^{18}$. In the present study, there was a highly significant association between older age group and the high risk of contracting Candida albicans DS $(\mathrm{OR}=3.62)$. This study result was different from that reported from Philadelphia by Bouquot $^{19}$, in which there was no different in the rate of DS with age, but similar to that reported from UK by Smaancyake et al., in which the highest rate occurred in older adult age $\operatorname{groups}^{20}$.

In the current study, there was a highly significant association between longer period of 18-over months and the high risk of contracting Candida albicans DS. This result was similar to that reported by Barbeau in which the risk of developing Candida albicans DS increased with time duration ${ }^{21}$. Furthermore, there was a highly significant association between the poor fitness and the high risk of contracting bacterial DS $(\mathrm{OR}=10.22$, and $p<0.001)$. This result was similar to that reported by Kulak in which poor-fitness was considered as a prime etiologic factor for contracting bacterial and/or Candida albicans $\mathrm{DS}^{22}$. This result explained by those poor-fitting dentures can increase mucosal trauma and ulcer formation. Most ulcers tend to have bacterial growth which sometimes might because of the non harmful normal flora, unless the count exceeds the normal and permissible levels which increase its ability to colonize both the denture and oral mucosal surfaces and cause stomatitis ${ }^{22}$. In the present study most of the patients were suffering from DS Type I which counted $66.7 \%$, while only $33.3 \%$ of the patients were suffering from DS in Type II, but no case of sever DS in Type III. These results were different from that reported by Pinelli et al., ${ }^{23}$ and Gendreau and Loewy et al., ${ }^{24}$ in which Type II was the most common presentation followed by type III lesions. The high rate of type II and III in other studies might be explained by that poor denture hygiene in their patients which allows the increased growth of pathogenic micro-organisms within the dental plaque on the fitting surfaces of dentures ${ }^{24}$.

\section{CONCLUSION}

DS is a circumstance that commonly affects denture wearers, and should be treated even if asymptomatic. The condition requires a combined treatment method from both patient and clinician, and the role of the patient must be stressed. Management of aetiological risk factors is key in order to prevent recurrence. Treatment modalities may consist of: treatment of any underlying systemic risk factors, improvement in the fit of existing dentures, replacement of existing dentures, improved denture hygiene and the use of antifungal and antibacterial agents. Either methods are employed; the main aim of treatment is to eradicate the bio film from the patient's dentures. Regular review of patients suffering from DS is essential in order to ensure longterm successful treatment of the condition.

\section{ACKNOWLEDGEMENTS}

Authors acknowledge the financial support of Sana'a University, Yemen.

\section{AUTHOR'S CONTRIBUTION}

The manuscript was carried out, written, and approved in collaboration with all authors.

\section{CONFLICT OF INTEREST}

No conflict of interest associated with this work.

\section{REFERENCES}

1. Salerno C, Pascale M, Contaldo M, Esposito V, Busciolano M, Milillo L, et al. Candida-associated denture stomatitis. Med Oral Patol Oral Cir Bucal 2011; 16:e13943. https://doi.org/10.4317/medoral.16.e139

2. Farah CS, Lynch N, McCullough MJ. Oral fungal infections: an update for the general practitioner. Aust Dent J 2010; 55:48-54 https://doi.org/10.1111/j.1834-7819.2010.01198.x

3. Hoshing C, Dixit S, Mootha A, Diwan N. Role of Candida albicans in denture stomatitis. J Indian Acad Oral Med Radiol 2011; 23:617-9. https://doi.org/10.24125/sanamed.v13i2.236

4. Dandekeri S, Prasad K, Shetty M, Hegde C, Sowmya MK, Jagadeesh M. Occurrence of streptococcus and Candida species and salivary ph in patients wearing complete denture. Int J Health Rehabil Sci 2013; 2:198-203.

5. Loster BW, Loster J, Wieczorek A, Ryniewicz W. Mycological analysis of the oral cavity of patients using 
acrylic removable dentures. Gastroenterol Res Pract 2012; 951572. https://doi.org/10.1155/2012/951572

6. Kanaguchi N, Narisawa N, Ito T, Kinoshita Y, Kusumoto $\mathrm{Y}$, Shinozuka O, et al. Effects of salivary protein flow and indigenous microorganisms on initial colonization of Candida albicans in an in vivo model. BMC Oral Health 2012; 12:36. https://doi.org/10.1186/1472-6831-12-36

7. Newton AV. Denture sore mouth. B Dent J. 1962; 357 3591.

8. Emami P, De Grandmont, Rompré PH, Barbeau J, Pan S, Feine JS. Favoring trauma as an etiological factor in denture stomatitis. J Dent Res 2008; 87: 440-444. https://doi.org/10.1177/154405910808700505

9. MacEntee MI, Glick N, Stolar E. Age, gender, dentures and oral mucosal disorders. Oral Dis 1998; 4(1):32-6. https://doi.org/10.1111/j.1601-0825.1998.tb00252.x

10. Zomorodian K, Haghighi NN, Rajaee N, Pakshir K, Tarazooie B, Vojdani M, et al. Assessment of Candida species colonization and denture-related stomatitis in complete denture wearers. Med Mycol 2011; 49:208-11. https://doi.org/10.3109/13693786.2010.507605

11. Abaci O, Haliki-Uztan A. Investigation of the susceptibility of Candida species isolated from denture wearers to different antifungal antibiotics. Afr J Microbiol Res 2011; 5:1398-403. https://doi.org/10.5897/AJMR10.693

12. Sampaio-Maia B, Figueiral MH, Sousa-Rodrigues $P$, Fernandes MH, Scully C. The effect of denture adhesives on Candida albicans growth in vitro. Gerodontol 2012; 29:348-56.https://doi.org/10.1111/j.1741-2358.2011.00478.x

13. Salim N, Moore C, Silikas N, Satterthwaite J, Rautemaa R. Candidacidal effect of fluconazole and chlorhexidine released from acrylic polymer. J Antimicrob Chemother 2013; 68:587-92. https://doi.org/10.1093/jac/dks452

14. Marra J, Paleari AG, Rodriguez LS, Leite ARP, Pero AC, Compagnoni MA. Effect of an acrylic resin combined with an antimicrobial polymer on biofilm formation. J Appl Oral Sci 2012; 20: 643-8.
https://doi.org/10.1590/S1678-77572012000600009

15. Prabha JL. Bacterial load in denture stomatitis. Pharm Sci Res 2015; 7(7):453-454

16. Harold Marcott, Marc C, Lavoie. Oral microbial ecology and role of salivary immunoglobin A. Microbiol Mol Biol Rev 1998; 62:1-10. PMID: 9529888

17. Gendreau L, Loewy ZG. Epidemiology and etiology of denture stomatitis. J Prosthodont 2011; 20(4): 251-60 https://doi.org/10.1111/j.1532-849X.2011.00698.x

18. Sadig W. The denture hygiene, denture stomatitis and role of the dental hygienist. Int J Dent Hyg 2010; 8(3): 227231. https://doi.org/10.1111/j.1601-5037.2009.00413.x

19. Bouquot Brad, W Neville, Douglas D Damm, Carl M. Allen, Jerry E. Oral and maxillofacial pathology $\left(2^{\text {nd }}\right.$ ed.). Philadelphia: W.B. Saunders 2002; 192-194. ISBN 0721690033

20. Samarmyke 2009 Samaranayake LP. Host factors and oral candidosis. In: Samaranayake LP, Mac Farlane TW, eds. Oral Candidosis. Bristol, UK: Wright. 1990: 66-103. https://doi.org/10.1080/10158782.2011.11441414

21. Barbeau J, Seguin J, Goulet JP, et al. Reassessing the presence of Candida albicans in denture-related stomatitis. Oral Surgery Oral Med Oral Pathology Oral radiology Endoddontis 2003; 95(1):51-9. https://doi.org/10.1067/moe.2003.44

22. Kulak, et al. 2002 29. Kulak Y, Arikan A, Delibalta N. Comparison of three different methods for generalized denture stomatitis. J Prothet Dent 1994; 72(3): 283-288 https://doi.org/10.1016/0022-3913(94)90341-7

23. Pinelli LA, Montandon AA, Moraes TA, Grassi Fais LA. Ricinus communis treatment of denture stomatitis in institutionalised elderly. J Oral Rehabil 2013; 40(5): 375380. https://doi.org/10.1111/joor.12039

24. Shulman JD, Rivera-Hidalgo F, Beach MM. Risk factors associated with denture stomatitis in the United States. J Oral Pathol Med 2005; 34(6): 340-346. https://doi.org/10.1111/j.1600-0714.2005.00287.x 